\title{
Determinants of Physical Activity Performed by Young Adults
}

\author{
Jacinto García-Fernández ${ }^{1, \dagger}$, José Rafael González-López ${ }^{1, *,+} \oplus$, Ángel Vilches-Arenas ${ }^{2}$ \\ and María de las Mercedes Lomas-Campos ${ }^{1}$ \\ 1 Nursing Department, Faculty of Nursing, Physiotherapy and Podiatry, Universidad de Sevilla, \\ 41009 Seville, Spain; jacintogf@us.es (J.G.-F.); mlomas@us.es (M.d.1.M.L.-C.) \\ 2 Preventive Medicine and Public Health Department, Faculty of Medicine and Faculty of Nursing, \\ Physiotherapy and Podiatry, Universidad de Sevilla, 41009 Seville, Spain; ava@us.es \\ * Correspondence: joserafael@us.es; Tel.: +34-954-556-362 \\ + These authors contributed equally to this work.
}

Received: 25 September 2019; Accepted: 21 October 2019; Published: 23 October 2019

\begin{abstract}
Despite the World Health Organization considering it important to promote physical activity as part of a healthy lifestyle, the official data show an increase in the percentage of physical inactivity, which has brought about the development of strategies at different levels (national and international) to reverse this trend. For the development of these strategies, it is relevant to know what the determinants of physical activity (at leisure and at work) are. Therefore, this is going to be analysed in the autochthonous young adults from Seville. A cross-sectional survey of their health behaviours was carried out. The sample was selected through a proportionally stratified random sampling procedure. From the results, we highlight that the general perceived health status is good and that most physical activity is performed during leisure time. However, a majority of the population analysed reported overweight or obesity. Participants with a low perceived health status, those who have low social support from their family and friends, and those who do not smoke are the ones who have more probability of engaging in physical activity during their leisure time. However, gender, education level, and alcohol consumption are revealed as determinants of the intensity of physical activity at work. In this regard, men and/or participants with a low level of studies are those who carry out more physically demanding activities at work.
\end{abstract}

Keywords: health status; health promotion; healthy lifestyle; leisure time; work; Spain

\section{Introduction}

Physical inactivity has been noted as the second leading modifiable risk factor for chronic disease (after smoking), and contributes significantly to total mortality in Western countries [1,2]. In addition, it is an important component affecting obesity-related chronic disease and the ability to maintain weight [3,4]. For all these reasons, the World Health Organization (WHO) considers it important to promote physical activity (PA) as part of a healthy lifestyle [5]. PA is defined by Caspersen et al. [6] as "any bodily movement produced by skeletal muscles that results in energy expenditure." That includes not only practising sports but also occupational, conditioning, household, or other activities [6].

Despite the importance of exercise or sport in health, the percentage of people from the EU who engage in some kind of exercise or sport has decreased in recent years, with the last reported level of inactivity in the EU being 46\% [7]. The data from Spain are quite close to the EU values, so the percentage of people who practise some kind of sport or exercise has been decreasing since 2009 .

For a decade, national and European strategies [8,9] have been devised to try to reverse this trend, so it is necessary to know what the determinants of performing PA are. Furthermore, PA interventions 
targeted at sedentary healthy adults are cost-effective [10]. There are, however, few studies about PA in young adults in contrast to other life cycle stages such as childhood, adolescence, and old age [11-13].

On this subject, Baunan et al. [14] proposed an ecological multilevel model of PA-individual, social, environmental and policy levels are considered-since the combination of different levels of factors is expected to influence the level of PA. In this model, they pointed out that the importance of each determinant of PA depends on the life cycle stage. In this case, determinants that theoretically have more influence in young adults are those related to the environment and policy, although individual and social factors may also have a significant effect on the level of PA of this group.

Previous research [15-20] has analysed demographic (gender, age, education), biological (health status, BMI), as well as social (support from family and friends) variables as determinants of PA in adults; however, the results are not homogeneous since the country in which the study is carried out plays an important role [7].

In this respect, according to the statistics [7] the percentage of people who perform PA varies according to age, gender, and education level. In this sense, the percentage of inactivity increases with age [21]. Therefore, while the level of inactivity in adolescents is $19 \%$, the number of people aged 55 or over who do not carry out any kind of exercise is 58\% [7]. Regarding gender, differences between men and women among adults are reported [22-27]. According to the WHO [28], women perform less PA than men. Nevertheless, women have a stronger adherence to PA recommendations than men $[29,30]$. As to the education level [7], the results revealed that if people left the educational system by the age of 15 or earlier, their inactivity level is higher $(68 \%)$ than if they finished their education at the age of 20 or over $(27 \%)$. According to the Programme for the International Assessment of Adult Competencies (PIACC) report [31], the percentage of people from Spain who did not finish secondary school in 2013 was around $47 \%$, which is almost double the average rate in Europe (26\%).

In addition, PA also depends on the perceived health status and the body mass index (BMI) category [18,32]. Considering that improving health status and weight control are the most common reasons for engaging in PA [7], it is expected that people with a lower level of self-perceived health and/or with a higher BMI are those who are more likely to perform PA.

Based on the data from the Ministry of Health, Social Services and Equality in Spain [33], 71\% of the population perceived their health status as being very good or good. According to Eurostat [34], in 2017 the population the European population aged 18 or over that was overweight (BMI equal to or greater than 25) was $52.0 \%$ and for obesity it was $15.2 \%$ (BMI equal to or greater than 30 ); the evidence is similar in Spain. BMI is also associated with national cultural factors [35], education level, and socioeconomic status [36].

Alcohol and tobacco consumption are not considered to be health-promoting behaviours $[37,38]$. Some research $[39,40]$ has described people who are physically active as also being likely to be moderate drinkers. Dodge et al. [41] relate high-intensity aerobic PA with a protective effect of alcohol compared with other kinds of PA. With respect to tobacco, some authors have found a negative association between PA and smoking [42].

Focusing on interpersonal variables, family [43] and friend [44] support has also been shown to have a positive association with PA. This is defined as "aid and assistance exchanged through social relationships and interpersonal transactions" [45]. As was argued by Scarapicchia et al. [46], although there is previous empirical evidence, it is inconsistent and so more research should be carried out in this area.

Considering that PA is a complex behaviour [47], and the previous inconclusive research and scarcity of studies focused on young adults, it is important to go deeper into the different determinants of PA. Therefore, the aim of this research is to study the determinants of PA carried out by autochthonous young adults from Seville. 


\section{Materials and Methods}

\subsection{Design and Sample}

A cross-sectional survey of health behaviours of young adults from Seville was carried out. Native adults aged 25-44 years old and living in Seville were invited to take part, because the objective was to analyse the behaviour of autochthonous inhabitants. Seville has 702,355 inhabitants and is the capital of the Regional Community of Andalusia, Spain. Data collection was carried out in Seville's 11 administrative districts, from January to May 2012. To obtain a representative sample, a proportionally stratified random sample was used, which took people's distribution by district, gender, and age into account. The minimum sample size was established at 383 people, following the criteria of González-López et al. [32]: (a) the number of adults included in the census in Seville, (b) a $95 \%$ reliability level, and (c) a $0.86 \%$ probability of finding some of the health behaviours studied.

Inclusion criteria were men or women (a) born and residing in any of the official neighbourhoods or census sections from the 11 administrative districts in Seville; (b) 25-44 years old; (c) able to communicate and understand the requirements of the study; and (d) who signed the informed consent document. The main exclusion criterion was experiencing a mental illness that prevented them from understanding the purpose of the study. The total number of people interviewed was 409 , due to the mortality of the sample (around 7\%).

Most of the respondents were contacted directly by the interviewer on the street or while waiting outside primary care centres. Potential participants were approached and informed of the aim of the study. The facts that participation was anonymous, that data collection and handling were confidential, and that the survey results might serve to improve the provision of educational programmes and health services were highlighted.

\subsection{Instrumentation}

Sections of the previously validated Behavioural Risk Factor Surveillance System questionnaire [48,49] were used. The questionnaire was read aloud, and the answers were tabulated by the interviewer.

PA variables included in the research are described in Table 1. While doing leisure time physical activity (LTPA) on a regular basis and the level of PA at work were used such as dependent variables of the regression analysis, the frequency and types of LTPA as well as the types of PA at work were used for descriptive purposes.

Table 1. Descriptions of PA variables.

\begin{tabular}{|c|c|}
\hline $\begin{array}{l}\text { Does Leisure Time Physical } \\
\text { Activity (LTPA) on a Regular Basis }\end{array}$ & Dummy Variable (Yes/No) \\
\hline Types of LTPA & $\begin{array}{c}\text { Yes, if it was carried out at least three times a week for at least } 30 \text { min: walking at } \\
\text { a brisk pace, walking at an intense pace, jogging/running, cycling at a brisk pace, } \\
\text { cycling at an intense pace, swimming at brisk pace, tennis, paddle-ball, soccer, } \\
\text { basketball, martial arts, aerobics and rhythmic gymnastics, weights and gym } \\
\text { apparatus, ballroom dancing, other PA. }\end{array}$ \\
\hline Frequency of LTPA & $\begin{array}{c}\begin{array}{c}\text { None, one, two, three, or more than three times per week during the week before } \\
\text { the interview. }\end{array}\end{array}$ \\
\hline Types of PA at work & $\begin{array}{l}\text { Standing, sitting, walking, carrying light loads, climbing stairs or going up } \\
\text { inclines, hard work. }\end{array}$ \\
\hline Level of PA at work & Low, moderate, intense. \\
\hline
\end{tabular}

In addition, socio-demographic characteristics (gender, age (from 25 to 44 years old), education level (without studies; primary, secondary, or university), employment status (employed, unemployed, or other situations), and district), self-perceived level of health (ranked from 1 to 5, from poor to excellent), BMI as calculated considering the height and weight self-reported by participants and classified following the protocol used for the DORICA study (Spanish Society for the Study 
of Obesity) [50] (normal weight, overweight and obesity), social support from friends and family (ranked 1 to 5, from always to never), current alcohol consumption (Yes/No, depending on whether the participant had drunk alcohol in the last 30 days), current tobacco consumption (Yes/No) were considered as independent variables in our analysis.

\subsection{Ethical Considerations}

All subjects gave their informed consent for inclusion before they participated in the study. Data collection was carried out exclusively by an interviewer. Consent forms and questionnaires were stored in a locked container. The data were transferred to a password-protected computer database. The study was conducted in accordance with the Declaration of Helsinki of 1975 (updated in 2013), and the protocol was approved by the Ethics Committee of the University of Seville (12/05/09).

\subsection{Statistical Analysis}

The data were analysed with the IBM SPSS Statistics package, version 25, for Windows (IBM, Armonk, NY, USA). The findings were reported using descriptive statistics. In addition, Logit and ordinal regression (depending on the characteristics of the dependent variable in each case) were tested. The models are specified as follows:

Model 1 and 2: LTPA $=ß 1+ß 2$ Gender $+ß 3$ Age $+\$ 4$ Employment $+\$ 5$ Health Status (BMI categories or self-perceived level of health) $+\$ 6$ Social Support $+\$ 7$ Alcohol $+\$ 8$ Tobacco $+\varepsilon$

Model 3 and 4: Intensity of PA at work $=B 1+B 2$ Gender $+B 3$ Age $+B 4$ Education level $+B 5$ Health Status (BMI categories or self-perceived level of health) $+\$ 6$ Social Support + B7 Alcohol $+\$ 8$ Tobacco $+\varepsilon$

Considering the majority of the variables are qualitative, some of them have been recoded to facilitate their inclusion in the models, such as the dummy variables employment ( 1 if the participant has a paid job, 0 otherwise), education level ( 1 if the participant has at least higher studies, 0 otherwise) and self-perceived health level ( 1 if excellent, very good or good, 0 if fair or poor).

\section{Results}

\subsection{Sample Demographic Characteristics and Health Status}

The sample was composed of 205 (50.1\%) men and 204 (49.9\%) women. The average age was 34.7 years (SD $=7.0$; [95\% CI: 34.0-35.3]). Almost half of the participants had completed a university $(43.5 \%)$ or secondary school level education $(42.3 \%)$. Two-thirds of the sample were employed $(62.6 \%)$; $84.8 \%$ of autochthonous young adults from Seville perceived their health status as good, very good, or excellent $(28.4 \%, 37.6 \%$, and $18.8 \%$, respectively), compared to $15.2 \%$ who perceived it as bad $(1.0 \%)$ or fair $(14.2 \%)$. The BMI of the studied population ranged between 19.1 and $47.1 \mathrm{~kg} / \mathrm{m}^{2}$, with an average of $28.6 \mathrm{~kg} / \mathrm{m}^{2}(\mathrm{SD}=3.9)$; almost $50 \%$ were classified as overweight and $33.7 \%$ were classified as obese. Only $16.4 \%$ of the sample reported a normal weight.

In relation to social support, 59.9\% always or almost always received support from their partner. Almost two-thirds of the sample always or almost always had support from their family or friends; $37.9 \%$ of the sample never received support from other people. With respect to current alcohol consumption, $87 \%$ of the participants had consumed alcohol in the last 30 days. Currently 194 people $(47.4 \%)$ smoked cigarettes and of them $134(67.0 \%)$ smoked daily.

\subsection{Physical Activity}

In this study, $78.5 \%$ of the people interviewed had engaged in some type of LTPA during the week before the survey was conducted; $38.6 \%$ of the sample reported that they carried out a single type of LTPA. The percentage decreased when the number of different PA activities increased; consequently, only $17.8 \%$ of autochthonous young adults from Seville performed at least three types of PA. A description of the types of PA can be seen in Figure 1. From these results, we highlight that 
four or more times a week $64.3 \%$ of the sample walked at a brisk pace and $56.2 \%$ walked at an intense pace. Furthermore, $10.8 \%$ of the participants went running twice per week; $9.8 \%$ practised cycling at a brisk pace three times a week. In addition, $4.9 \%$ of the sample played soccer twice a week, $4.6 \%$ practised aerobics and rhythmic gymnastics, and $5.1 \%$ used weights and gym apparatus with the same weekly frequency.

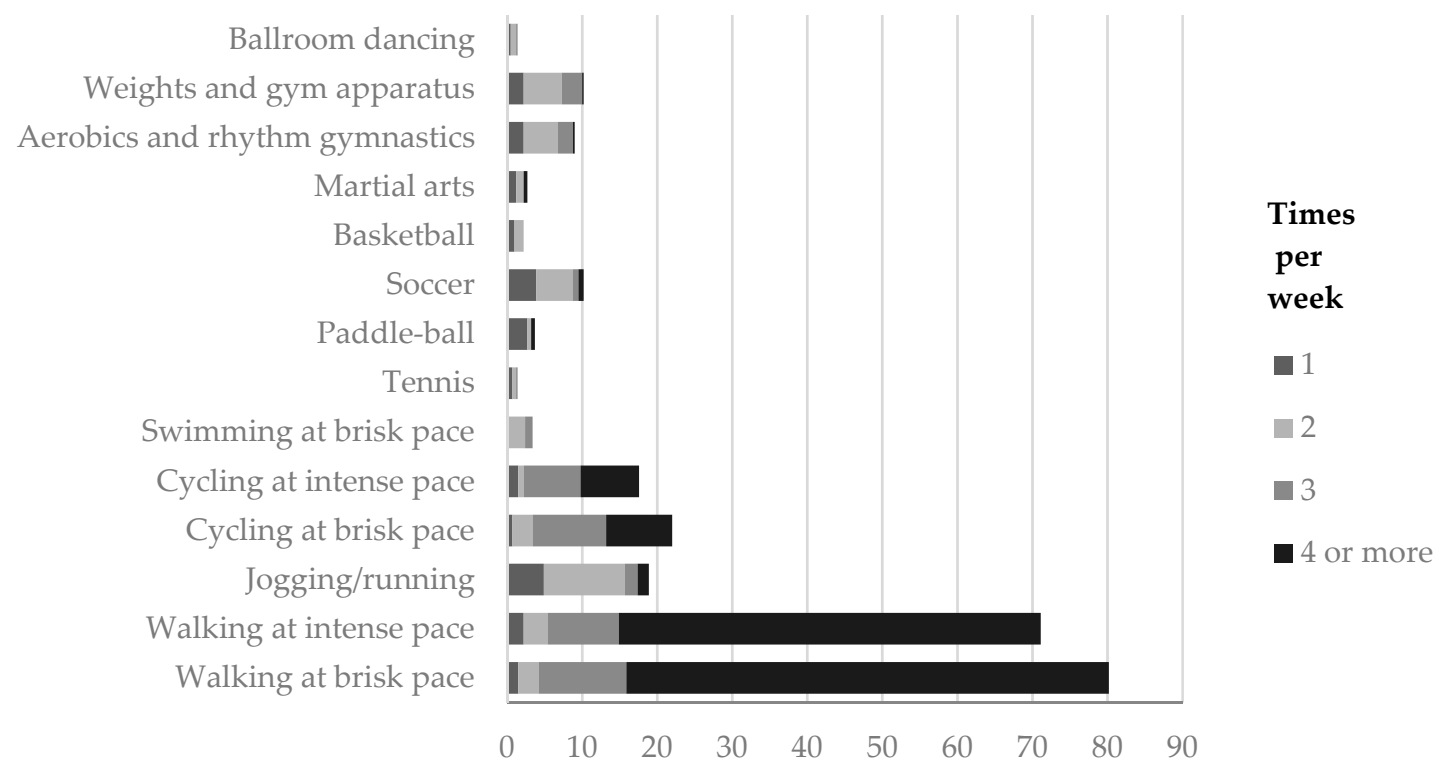

Figure 1. Types of LTPA of at least $30 \mathrm{~min}$.

Moreover, $80.1 \%$ of the respondents reported low PA at work, compared to $19.9 \%$ who said that their activity was intense $(18.7 \%)$ or moderate $(1.2 \%)$. The most frequently reported physical activities at work were standing or sitting $(71 \%)$, followed by walking $(17.9 \%)$, and transporting light loads or frequently going up stairs or inclines (3.9\%). Only $1.8 \%$ referred to performing heavy work that demands a lot of effort.

Table 2 shows the results of the regressions so we can see what the determinants of LTPA are. Social support from family and friends, and alcohol and tobacco consumption, had a statistically significant impact on the probability of carrying out LTPA. Considering that the social support variable is inverted, people who had less social support were more likely to engage in LTPA. While alcohol consumption had a positive impact on the likelihood of performing LTPA, tobacco consumption had a negative effect. Although the results on alcohol consumption are surprising, we must point out that this variable only considers whether the participant had consumed some alcohol in the last 30 days; it does not reflect whether their consumption was excessive or not.

In addition, the health status variables' results differed. Whereas the different BMI categories did not indicate any significant impact on the LTPA, the self-perceived level of health had a statistically significant, negative effect. Considering how this variable is defined, these results imply that people with a lower self-perceived level of health are more likely to carry out LTPA.

The determinants of the level of PA at work are presented in Table 3. Education level and gender are revealed as the variables that most influence the level of PA at work. People with a higher level of education perform low-intensity PA at work, while male gender implies that the kind of physical activities required at work are more intense. In addition, alcohol consumption presents a statistically significant, negative impact on the intensity of PA at work. The participants who had not drunk alcohol in the last 30 days perform more intense physical activities at work, while those who consumed alcohol in this period carry out less intense physical activities. Finally, the health status did not influence the intensity of PA carried out at work. 
Table 2. Results of logit regression of LTPA.

\begin{tabular}{ccc}
\hline Variable & Model 1 & Model 2 \\
\hline Constant & 1.579 & $4.599^{*}$ \\
Gender & -0.694 & -0.504 \\
Age & -0.035 & -0.055 \\
Employment status & 0.638 & 0.632 \\
Self-perceived level of heath & & $-2.273^{*}$ \\
BMI & -0.081 & \\
Overweight & -0.0195 & \\
Obesity & $0.857^{* * *}$ & $0.619^{*}$ \\
\hline Social support from friends and & $1.734^{* * *}$ & $2.007^{* * *}$ \\
family & $-1.736^{* * *}$ & $-1.981^{* * *}$ \\
Alcohol & $40.13^{* * *}$ & $46.06^{* * *}$ \\
Tobacco & & \\
\hline
\end{tabular}

Significance level: ${ }^{* *} p$-value $<0.005,{ }^{* *} p$-value $<0.01,{ }^{*} p$-value $<0.05$.

Table 3. Results of logit regression of level of PA at work.

\begin{tabular}{|c|c|c|}
\hline Variable & Model 3 & Model 4 \\
\hline Gender & $1.559^{* * *}$ & $1.405^{* * *}$ \\
\hline Age & -0.011 & 0.009 \\
\hline Education level & $-1.100^{* * *}$ & $-1.147^{* * *}$ \\
\hline $\begin{array}{l}\text { Self-perceived level of health } \\
\text { BMI }\end{array}$ & & 0.766 \\
\hline Overweight & -0.404 & \\
\hline Obesity & 0.458 & \\
\hline $\begin{array}{l}\text { Social support from friends and } \\
\text { family }\end{array}$ & 0.237 & -0.217 \\
\hline Alcohol & $-1.718^{* *}$ & $-1.488 *$ \\
\hline Tobacco & -0.096 & 0.175 \\
\hline Likelihood ratio statistics $\chi^{2}$ & $39.36^{* * *}$ & $35.63 * * *$ \\
\hline
\end{tabular}

\section{Discussion}

According to the results, the average profile of young autochthonous adults in the city of Seville and, therefore, in the sample, was: male or female, with an average age of 35 years old, having university studies or secondary education, who performs a paid job and perceives their health status as good, very good, or excellent (especially men) and is overweight. Regarding PA, their work did not require very intense PA, while most of them declared that they performed LTPA.

With regard to LTPA, the percentage of people who did no PA at all, or did not do PA regularly (just over 21.5\%), was close to that established by the Andalusian health survey (25.3\%) in the same age range [51], and lower than in the Spanish survey (around 30-35\%) of the adult population of 18 to 49 years old [26], or $58 \%$ of people aged 55 or over, published more recently by the European Commission [7]. There are no data regarding other studies in our city, so we cannot interpret the figures according to a trend, in a similar way to that established by Redondo et al. [52] in Gerona, by the SIVFRENT-A study in Madrid [25,53], or by the Spanish national survey [54]. In our study, the likelihood of carrying out LTPA was not influenced by age. However, previous research $[7,21,51]$ has supported the notion that inactivity increases with age. In this sense, it is necessary to point out that the sample does not include older people, who are usually reported as the group with the highest level of inactivity. 
Although some previous evidence supports gender having an influence on the probability of engaging in LTPA $[15,16]$, our findings suggest that this is not a statistically significant relationship. However, as Artazcoz et al. [55] argue, "the gender differences in activity in leisure time can be explained by cultural patterns that encourage more sports among men, but also by the time constraints related to greater occupation of women (work and housework)." In our study the fact of being employed or not had no effect on the probability of performing LTPA. In this sense, Päivärinne et al. [56] described an inverse linear relationship between LTPA and the number of years working.

When we related LTPA to the level of self-perceived health, our data showed a statistically significant, negative effect. This can be explained by people who generally have a lower perception of their health being those who report a higher probability of engaging in PA, since they consider PA as the way to improve their health. This is also supported by recent evidence from the USA [57]. On the contrary, the self-perceived health level had a positive, direct effect on LTPA in Finnish people aged 46 years old [58]. The difference between these results and those obtained by our analysis could be due to the sample composition and the cultural impact.

Focusing on the social support variable, our findings suggest an inverse relationship with the practice of LTPA. This may be due to the fact that people who have less support perform PA to curry social relationships [7]. As examples, various studies in people over 44 years old $[43,44,59]$ state that there is a direct relationship between the support of family and friends and the performance of PA.

Alcohol consumption has a positive impact on the likelihood of carrying out LTPA. In this sense, we need to clarify that this measure does not have any negative connotation since it only records whether the participant has consumed alcohol in the last 30 days. Alcohol consumption can simply be considered as another way of socialising, which could be due to celebrating with peers reaching some kind of objectives $[39,40,47]$. However, our findings reveal an inverse impact of tobacco consumption on LTPA. Our data from young adults are in line with those reported by Kwan et al. [60]. Other research $[61,62]$ also describes the negative association between PA and smoking, since smokers have a limited lung capacity, which means that PA is more difficult for them.

With regard to PA at work, gender and educational levels show a significant influence on the level of PA. As to gender, we argue that the most demanding physically intense jobs are usually carried out by men, which implies gender inequality [63]. In addition, Pulakka et al. [64] also report that PA differs by gender during working time.

Our data $(80.1 \%)$ on the low intensity of PA at work showed a somewhat lower percentage than those offered by health surveys in Andalusia (82.5\%) in the same age stratum [51], and in Spain (82.6\%) in the population between 25 and 64 years old [26]. These differences are possibly related to the job of the people surveyed. Yet they are not significant enough for us to be able to establish any hypothesis on this subject.

In this regard, our results reveal that a higher educational level is related to a lower level of PA at work. If the level of studies is higher, this person will probably be in charge of other, less physically demanding duties.

Finally, a negative impact of alcohol consumption on PA at work is evident. The main reason may be responsibility about its consumption and subsequent working hours, as well as the intensity of the PA. We have not found a relationship between the level of PA at work and tobacco consumption or social support.

\section{Limitations and Future Research Directions}

The data were based on self-reports and were not verified using other methods. In this respect, the level of PA at work was a self-reported measure, although participant perception may depend on an individual's previous exercise experience and relative level of fitness. Future research on this topic should control the self-reported measures with objective data such as Metabolic Equivalent of Tasks (METs). 
Although the cross-sectional design allowed us to establish some factors that have an influence on the PA, they are mainly based on the individual at the social level of the model proposed by Bauman et al. [14], so it is necessary to go further in the analysis of the determinants of PA by considering variables from the environment and policy levels.

Since the results obtained are very sensitive to a country culture's, it would be relevant to carry out this kind of study in other contexts in order to be able to develop specific public health policies that encourage PA.

\section{Conclusions}

At the beginning of our research, we stated that our objective was to go further into the determinants of PA (at leisure and at work) carried out by autochthonous young adults from Seville.

A majority of participants performed LTPA, with walking, cycling, and running being the most popular activities. Based on the findings, the participants engaged in LTPA mainly due to a poor self-perceived state of health or for socialisation purposes. In addition, smokers less often perform LTPA.

In general, the job activities of participants were not very physically demanding, although more intense activities were carried out by men and/or people with a low education level. Furthermore, people who consumed alcohol carried out less intense PA at work.

As the level of physical inactivity reported in young adults was lower than in other contexts, different city institutions should encourage PA due to its importance for health; therefore, they should develop some strategies to achieve lower levels of physical inactivity. Therefore, specific strategies should be implemented for each age group (adolescents, young adults, and older people), since their characteristics are different.

For the development of these strategies in young adults, the insights from this research could be useful since the main determinants of PA are reported.

Author Contributions: Conceptualisation, J.G.-F.; J.R.G.-L.; Á.V.-A. and M.d.1.M.L.-C.; Methodology, J.G.-F., J.R.G.-L., Á.V.-A. and M.d.1.M.L.-C.; Formal Analysis, J.G.-F., J.R.G.-L., Á.V.-A. and M.d.1.M.L.-C.; Writing一Original Draft Preparation, J.G.-F., J.R.G.-L., Á.V.-A. and M.d.1.M.L.-C.; Writing-Review and Editing, J.G.-F., J.R.G.-L.

Funding: This research was funded by the Government of Andalusia in 2009 for the project "Analysis of health behaviours and disease prevalence of the immigrant and native population of the city of Seville" (PI-0138).

Acknowledgments: The authors would like to thank all the participants who took part in this study.

Conflicts of Interest: The authors declare no conflicts of interest. The funders had no role in the design of the study; in the collection, analyses, or interpretation of data; in the writing of the manuscript; or in the decision to publish the results.

\section{References}

1. Mathers, C.D.; Vos, E.T.; Stevenson, C.E.; Begg, S.J. The Australian burden of disease study: Measuring the loss of health from diseases. Injuries and risk factors. Med. J. Aust. 2000, 172, 592-596. [CrossRef] [PubMed]

2. U.S. Department of Health and Human Services. Physical Activity and Health: A Report of the Surgeon General; US Department of Health and Human Services, Centers for Disease Control and Prevention, National Center for Chronic Disease Prevention and Health Promotion: Atlanta, GA, USA, 1996.

3. Foright, R.M.; Presby, D.M.; Sherk, V.D.; Kahn, D.; Checkley, L.A.; Giles, E.D.; Bergouignan, A.; Higgins, J.A.; Jackman, M.R.; Hill, J.O.; et al. Is regular exercise an effective strategy for weight loss maintenance? Physiol. Behav. 2018, 188, 86-93. [CrossRef] [PubMed]

4. Wiklund, P. The role of physical activity and exercise in obesity and weight management: Time for critical appraisal. J. Sport Health Sci. 2016, 5, 151-154. [CrossRef] [PubMed]

5. World Health Organization. Global Recommendations on Physical Activity for Health. Available online: http://apps.who.int/iris/bitstream/10665/44399/1/9789241599979_eng.pdf (accessed on 16 October 2019).

6. Caspersen, C.J.; Powell, K.E.; Christenson, G.M. Physical activity, exercise, and physical fitness: Definitions and distinctions for health-related research. Public Health Rep. 1985, 100, 126-130. [PubMed] 
7. European Commission. Special Eurobarometer 412-Sport and Physical Activity. Available online: https://ec. europa.eu/commfrontoffice/publicopinion/archives/eb_special_419_400_en.htm\#412 (accessed on 16 October 2019).

8. Ministerio de Sanidad, Servicios Sociales e Igualdad. Actividad Física para la Salud y Reducción del Sedentarismo. Recomendaciones para la Población; Ministerio de Sanidad, Servicios Sociales e Igualdad; Estrategia de Promoción de la Salud y Prevención en el SNS: Madrid, Spain, 2015.

9. European Union Law. Recomendación del Consejo, de 26 de Noviembre de 2013, Sobre la Promoción de la Actividad Física Beneficiosa para la Salud en Distintos Sectores (2013/C 354/01). Available online: https://eur-lex.europa.eu/legal-content/ES/TXT/?uri=uriserv:OJ.C_.2013.354.01.0001.01.SPA\&toc=OJ: C:2013:354:TOC (accessed on 16 October 2019).

10. Müller-Riemenschneider, F.; Reinhold, T.; Willich, S.N. Cost-effectiveness of interventions promoting physical activity. Br. J. Sports Med. 2009, 43, 70-76. [CrossRef]

11. Bronikowski, M.; Bronikowska, M.; Maciaszek, J.; Glapa, A. Maybe it is not a goal that matters: A report from a physical activity intervention in youth. J. Sports Med. Phys. Fitness 2018, 58, 348-355.

12. Pluta, B.; Bronikowska, M.; Tomczak, M.; Laudańska-Krzemińska, I.; Bronikowski, M. Family leisure-time physical activities-Results of the "Juniors for Seniors" 15-week intervention programme. Biomed. Hum. Kinetics 2017, 9, 165-174. [CrossRef]

13. Bronikowski, M.; Bronikowska, M.; Pluta, B.; Maciaszek, J.; Tomczak, M.; Glapa, A. Positive impact on physical activity and health behaviour changes of a 15-week family focused intervention program: "Juniors for Seniors". BioMed Res. Int. 2016, 2016, 5489348. [CrossRef]

14. Bauman, A.E.; Reis, R.S.; Sallis, J.F.; Wells, J.C.; Loos, R.J.F.; Martin, B.W. The Lancet Physical Activity Series Working Group. Correlates of Physical Activity: Why Are Some People Physically Active and Others Not? Lancet 2012, 380, 258-271. [CrossRef]

15. Trost, S.G.; Owen, N.; Bauman, A.E.; Sallis, J.F.; Brown, W. Correlates of adults' participation in physical activity: Review and update. Med. Sci. Sports Exerc. 2002, 34, 1996-2001. [CrossRef]

16. Rhodes, R.E.; Martin, A.D.; Taunton, J.E.; Rhodes, E.C.; Donnelly, M.; Elliot, J. Factors associated with exercise adherence among older adults: An individual perspective. Sports Med. 1999, 28, 397-411. [CrossRef] [PubMed]

17. Kaewthummanukul, T.; Brown, K.C. Determinants of employee participation in physical activity: Critical review of the literature. AAOHN J. 2006, 54, 249-261. [CrossRef] [PubMed]

18. Allender, S.; Hutchinson, L.; Foster, C. Life-change events and participation in physical activity: A systematic review. Health Promot. Int. 2008, 23, 160-172. [CrossRef] [PubMed]

19. Van Stralen, M.M.; de Vries, H.; Mudde, A.N.; Bolman, C.; Lechner, L. Determinants of initiation and maintenance of physical activity among older adults: A literature review. Health Psychol. Rev. 2009, 3, 147-207. [CrossRef]

20. Humpel, N.; Owen, N.; Leslie, E. Environmental factors associated with adults participation in physical activity: A review. Am. J. Prev. Med. 2002, 22, 58-69. [CrossRef]

21. Lox, C.L.; Martin, K.A.; Petruzzello, S.J. The Psychology of Exercise: Integrating Theory and Practice, 4th ed.; Holcomb Hathaway: Scottsdale, AZ, USA, 2014.

22. Jilcott, S.B.; Vu, M.B.; Morgan, J.; Keyserling, T.C. Promoting use of nutrition and physical activity community resources among women in a family planning clinic setting. Women Health 2012, 52, 55-70. [CrossRef]

23. Cai, S.R.; Zhu, H.H.; Li, Q.R.; Mae, X.Y.; Yao, K.Y.; Zhang, S.Z.; Zheng, S. Gender disparities in dietary status and its risk factors in underserved populations. Pub. Health 2012, 126, 324-331. [CrossRef]

24. Eguchi, E.; Iso, H.; Tanabe, N.; Wada, Y.; Yatsuya, H.; Kikuchi, S.; Inaba, Y.; Tamakoshi, A. Japan Collaborative Cohort Study Group. Healthy Lifestyle Behaviours and Cardiovascular Mortality Among Japanese Men and Women: The Japan Collaborative Cohort Study. Eur. Heart J. 2012, 33, 467-477. [CrossRef]

25. Díaz-Olalla, J.M.; Benítez-Robredo, T. Estudio de Salud de la Ciudad de Madrid 2014; Ayuntamiento de Madrid: Madrid, Spain, 2015.

26. Suárez, M.; Neira, M.; Pastor, M.T.; Ichaso, M.S. Encuesta Nacional de Salud. España 2011/12. Serie Informes Monográficos $n^{\circ} 4$. Actividad Física. Descanso y Ocio; Ministerio de Sanidad. Servicios Sociales e Igualdad: Madrid, Spain, 2014. 
27. Rodríguez-Romo, G.; Cordente, C.A.; Mayorga, J.I.; Garrido-Muñoz, M.; Macías, R.; Lucía, A.; Ruiz, J.R. Influencia de determinantes socio-demográficos en la adherencia a recomendaciones de actividad física en personas de entre 15 y 74 años de Madrid. Revista Espanola Salud Publica 2011, 85, 351-362. [CrossRef]

28. World Health Organization. Physical inactivity: A global public health problem. Available online: http://www.who.int/dietphysicalactivity/factsheet_inactivity/en/ (accessed on 16 October 2019).

29. Hansen, B.H.; Kolle, E.; Steene-Johannessen, J.; Dalene, K.E.; Ekelund, U.; Anderssen, S.A. Monitoring population levels of physical activity and sedentary time in Norway across the lifespan. Scand. J. Med. Sci. Sports 2019, 29, 105-112. [CrossRef]

30. Baptista, F.; Santos, D.A.; Silva, A.M.; Mota, J.; Santos, R.; Vale, S.; Ferreira, J.P.; Raimundo, A.M.; Moreira, H.; Sardinha, L.B. Prevalence of the Portuguese population attaining sufficient physical activity. Med. Sci Sports Exerc. 2012, 44, 466-473. [CrossRef] [PubMed]

31. Ministerio de Educación, Cultura y Deporte. Programme for the International Assessment of Adult Competencies. 2013 Informe español (PIACC). Available online: https://sede.educacion.gob.es/publiventa/ piaac-programa-internacional-para-la-evaluacion-de-las-competencias-de-la-poblacion-adulta-2013informe-espanol-/educacion-ensenanza-union-europea/16156 (accessed on 16 October 2019).

32. González-López, J.R.; Rodríguez-Gázquez, M.A.; Lomas-Campos, M.M. Physical Activity in Latin American Immigrant Adults Living in Seville, Spain. Nurs Res. 2015, 64, 476-484. [CrossRef] [PubMed]

33. Ministerio de Sanidad, Servicios Sociales e Igualdad. Informe Anual del Sistema Nacional de Salud 2017. Available online: https:/www.mscbs.gob.es/estadEstudios/estadisticas/sisInfSanSNS/tablasEstadisticas/ InfAnSNS.htm (accessed on 16 October 2019).

34. Eurostat; European Commission. European Core Health Indicators. Obesity Rate by Body Mass Index (BMI). 2017. Available online: https://ec.europa.eu/eurostat/tgm/refreshTableAction.do?tab=table\&plugin= $1 \&$ pcode=sdg_02_10\&language $=$ en (accessed on 16 October 2019).

35. Masood, M.; Aggarwal, A.; Reidpath, D.D. Effect of national culture on BMI: A multilevel analysis of 53 countries. BMC Public Health 2019, 19, 1212. [CrossRef] [PubMed]

36. Aranceta, J.; Perez-Rodrigo, C.; Serra-Majem, L.; Ribas, L.; Quiles-Izquierdo, J.; Vioque, J.; Foz, M. Spanish Collaborative Group for the Study of Obesity. Influence of sociodemographic factors in the prevalence of obesity in Spain. The SEEDO'97 Study. Eur. J. Clin. Nutr. 2001, 55, 430-435. [CrossRef] [PubMed]

37. Leasure, J.L.; Neighbors, C.; Henderson, C.E.; Young, C.M. Exercise and alcohol consumption: What we know, what we need to know, and why it is important. Front. Psychiatry 2015, 6, 156. [CrossRef]

38. Heydari, G.; Hosseini, M.; Yousefifard, M.; Asady, H.; Baikpour, M.; Barat, A. Smoking and Physical Activity in Healthy Adults: A Cross-Sectional Study in Tehran. Tanaffos 2015, 14, 238-245.

39. Centers for Disease Control. Fact Sheets-Alcohol Use and Health. Available online: https://www.cdc.gov/ alcohol/fact-sheets/alcohol-use.htm (accessed on 16 October 2019).

40. Lisha, N.E.; Martens, M.; Leventhal, A.M. Age and gender as moderators of the relationship between physical activity and alcohol use. Addict. Behav. 2011, 36, 933-936. [CrossRef]

41. Dodge, T.; Clarke, P.; Dwan, R. The relationship between physical activity and alcohol use among adults in the United States: A systematic review of the literature. Am. J. Health Promot. 2017, 31, 97-108. [CrossRef]

42. Strine, T.W.; Okoro, C.A.; Chapman, D.P.; Balluz, L.S.; Ford, E.S.; Ajani, U.A.; Mokdad, A.H. Health-related quality of life and health risk behaviors among smokers. Am. J. Prev Med. 2005, 28, 182-187. [CrossRef]

43. Smith, G.L.; Banting, L.; Eime, R.; O'Sullivan, G.; Van Uffelen, J.G. The association between social support and physical activity in older adults: A systematic review. Int. J. Behav. Nutr. Phys. Act. 2017, 14, 56. [CrossRef]

44. Sarkar, S.; Taylor, W.C.; Lai, D.; Shegog, R.; Paxton, R.J. Social support for physical activity: Comparison of family, friends, and coworkers. Work 2016, 55, 893-899. [CrossRef] [PubMed]

45. Heaney, C.A.; Israel, B.A. Social networks and social support. In Health Behavior and Health Education, 4th ed.; Glanz, K., Rimer, B.K., Viswanath, K., Eds.; Jossey-Bass: San Francisco, CA, USA, 2008; pp. 189-210.

46. Scarapicchia, T.M.F.; Amireault, S.; Faulkner, G.; Sabiston, C.M. Social support and physical activity participation among healthy adults: A systematic review of prospective studies. Rev. Sport Exerc. Psychol. 2017, 10, 50-83. [CrossRef]

47. Conroy, D.E.; Pincus, A.L.; Ram, N.; Al'Absi, M. Thirsting to understand the temporal dynamics of physical activity and alcohol use. Br. J. Sports Med. 2018, 52, 1158-1159. [CrossRef] [PubMed] 
48. Centers for Disease Control and Prevention. Surveillance of certain health behaviors among states and selected local areas-Behavioral risk factor surveillance system. United States. MMWR Surveill. Summ. 2010, $59,1-221$.

49. García-Fernández, J. Análisis de las conductas de salud de la población autóctona adulta joven de la ciudad de Sevilla. Ph.D. Thesis, Universidad de Sevilla, Sevilla, Spain, 26 September 2017.

50. Aranceta, J.; Pérez, C.; Serra, L.; Vioque, J.; Tur, J.A.; Mataix, J. Dorica study: Dyslipidemia. obesity and cardiovascular risk. In Obesity and Cardiovascular Risk. Dorica Study; Aranceta, J., Foz, M., Gil, B., Jover, E., Mantilla, T., Millan, J., Eds.; Panamericana: Madrid, Spain, 2004.

51. Sánchez, J.J. Encuesta Andaluza de Salud 2011-2012. Muestra de Adultos; Consejería de Igualdad, Salud y Políticas Sociales, Escuela Andaluza de Salud Pública, Junta de Andalucía: Seville, Spain, 2013.

52. Redondo, A.; Subirana, I.; Ramos, R.; Solanas, P.; Salaf, J.; Masiá, R.; Schröder, H.; Marrugat, J.; Elosua, R. Tendencias en la práctica de actividad física en el tiempo libre en el periodo 1995-2005 en Girona. Rev. Esp. Cardiol. 2011, 64, 997-1004. [CrossRef]

53. Díez-Gañán, L. Hábitos de Salud en la Población Adulta de la Comunidad de Madrid 2011. Resultados del Sistema de Vigilancia de Factores de Riesgo Asociados a Enfermedades No Transmisibles en Población Adulta (SIVFRENT-A); Boletín Epidemiológico de la Comunidad de Madrid No10. Servicio de Epidemiología. Consejería de Sanidad de la Comunidad de Madrid: Madrid, Spain, 2012.

54. Ministerio de Sanidad, Servicios Sociales e Igualdad. La Encuesta Europea de Salud en España Subdirección General de Información Sanitaria e Innovación; Dirección General de Salud Pública, Calidad e Innovación. Ministerio de Sanidad, Servicios Sociales e Igualdad: Madrid, Spain, 2015.

55. Artazcoz, L.; Moya, C.; Vanaclocha, H.; Pont, P. La salud de las personas adultas. Gac. Sanit. 2004, 18, 56-68. [CrossRef]

56. Päivärinne, V.; Kautiainen, H.; Heinonen, A.; Kiviranta, I. Relationships of leisure-time physical activity and work ability between different occupational physical demands in adult working men. Int. Arch. Occup. Environ. Health 2019, 92, 739-746. [CrossRef]

57. Ross, A.; Cloutier, S.; Searle, M. The association between leisure time physical activity and happiness: Testing the indirect role of health perception. J. Community Psychol. 2019, 47, 1169-1183. [CrossRef]

58. Niemelä, M.S.; Kangas, M.; Ahola, R.J.; Auvinen, J.P.; Leinonen, A.M.; Tammelin, T.H.; Vaaramo, E.S.; Keinänen-Kiukaanniemi, S.M.; Korpelainen, R.I.; Jämsä, T.J. Dose-response relation of self-reported and accelerometer-measured physical activity to perceived health in middle age-the Northern Finland birth cohort 1966 study. BMC Public Health 2019, 19, 21. [CrossRef]

59. Gyasi, R.M. Social support, physical activity and psychological distress among community-dwelling older Ghanaians. Arch. Gerontol. Geriatr. 2019, 81, 142-148. [CrossRef]

60. Kwan, M.; Bobko, S.; Faulkner, G.; Donnelly, P.; Cairney, J. Sport participation and alcohol and illicit drug use in adolescents and young adults: A systematic review of longitudinal studies. Addict. Behav. 2014, 39, 497-506. [CrossRef] [PubMed]

61. Salin, K.; Kankaanpää, A.; Hirvensalo, M.; Lounassalo, I.; Yang, X.; Magnussen, C.G.; Hutri-Kähönen, N.; Rovio, S.; Viikari, J.; Raitakari, O.T.; et al. Smoking and physical activity trajectories from childhood to midlife. Int. J. Environ. Res. Public Health 2019, 16, 974. [CrossRef] [PubMed]

62. Monga, D.; Goel, S.; Padhy, S. Level of physical activity and its relationship with tobacco use among youth: A cross-sectional survey in North India. Indian J. Community Health 2018, 30, 348-353. [CrossRef]

63. Gascoigne, C.; Parry, E.; Buchanan, D. Extreme work, gendered work? How extreme jobs and the discourse of 'personal choice'perpetuate gender inequality. Organization 2015, 22, 457-475. [CrossRef]

64. Pulakka, A.; Leskinen, T.; Koster, A.; Pentti, J.; Vahtera, J.; Stenholm, S. Daily physical activity patterns among aging workers: The Finnish Retirement and Aging Study (FIREA). Occup. Environ. Med. 2019, 76, 33-39. [CrossRef] [PubMed]

(C) 2019 by the authors. Licensee MDPI, Basel, Switzerland. This article is an open access article distributed under the terms and conditions of the Creative Commons Attribution (CC BY) license (http://creativecommons.org/licenses/by/4.0/). 